\title{
Pendekatan Partisipatoris Dalam Pengelolaan Sumberdaya Arkeologis Dan Kemungkinan Penerapannya Di Kawasan Arkeologis Gunung Kidul
}

\section{Tjahjono Prasodjo}

Keywords: cultural resource management, method, theory, practices, heritage, conservation

\section{How to Cite:}

Prasodjo, T. (2000). Pendekatan Partisipatoris Dalam Pengelolaan Sumberdaya Arkeologis Dan Kemungkinan Penerapannya Di Kawasan Arkeologis Gunung Kidul. Berkala Arkeologi, 20(1), 151-162. https:/ / doi.org/10.30883/jba.v20i1.814

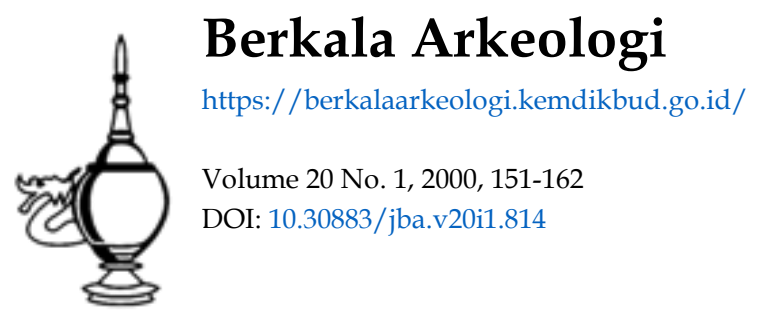




\title{
PENDEKATAN PARTISIPATORIS \\ DALAM PENGELOLAAN SUMBERDAYA ARKEOLOGIS \\ DAN KEMUNGKINAN PENERAPANNYA \\ DI KAWASAN ARKEOLOGIS GUNUNG KIDUL*)
}

\author{
Tjahjono Prasodjo \\ (Jurusan Arkeologi, Fakultas Sastra, Universitas Gadjah Mada)
}

\section{Pendahuluan}

Artikel dalam Harian Kompas tanggal 31 Mei 2000 memberitakan serangkaian pencurian benda-benda cagar budaya di daerah Jawa Tengah. Menurut data yang disampaikan oleh SPSP kepada Kompas, dari tahun 1974 hingga tahun 2000 tercatat 86 kasus pencurian benda cagar budaya dengan scbanyak 133 biah tinggalan budaya lenyap. Dalam artikel yang sama juga dikemukakan tentang adanya penjarahan tanah di situs Dieng oleh petani lokal. Dari 80 ha. lahan situs percandian Dieng yang telah ditetapkan oleh keputusan Gubernur Hindia Belanda pada tahun 1937, kini tinggal 34 ha. saja. Lahan seluas 46 ha. sisanya telah dimanfaatkan oleh pctani lokal. Lebih ironis lagi, sebagian tanah tersebut bahkan sudah disertifikatkan atas nama para petani lokal. Bahkan akhir-akhir ini dari 34 ha. tersebut, scbagian sudah dipakai petani lokal untuk bertanam kentang. Penanaman kentang juga sudah mulai mendekati bangunan candi, antara lain di situs Dharmapala (Kompas, 31 Mei 2000).

Berita tersebut di atas merupakan gambaran kecil dari ketidakmampuan manajemen sumberdaya arkeologis di Indonesia. Manajemen sumberdaya arkeologis atau sering juga disebut dengan "pengelolaan sumberdaya arkeologis" akhir-akhir ini sering kali mendapatkan perhatian yang cukup besar, baik dari kalangan akademisi, praktisi, maupun dari kalangan masyarakat luas. Perhatian yang besar tersebut dikarenakan munculnya banyak kasus-kasus pencurian maupun penjarahan situs-situs purbakala di Indonesia. Untuk mengatasi berbagai kasus dalam bidang pengclolaan sumberdaya arkeologis di Indonesia, nampaknya diperlukan sebuah paradigma pengelolaan baru yang lain dari yang telah dilakukan selama ini. Makalah ini mencoba menawarkan sebuah pendekatan baru dalam pengelolaan sumberdaya arkeologis di Indonesia, dengan menyajikan studi kasus di Gunung Kidul, D. I. Yogyakarta.

-) Disampaikan dalam "Seminar Penelitian Terpadu Kawasan Arkeologis Gunungkidul 2000: Alternatif Pengembangan Potensi Arkeologis di Kawasan Gunungkidul", 12-13 April 2000, Fakultas Sastra - Universitas Gadjah Mada, Yogyakarta. 


\section{A. Pengertian dan Definisi Pengelolaan Sumberdaya Arkeologis}

Konsep "pengelolaan sumberdaya arkeologis" yang benar sebetulnya belum begitu lama dikenal di Indonesia, walaupun sebenarnya secara praktis sudah dilaksanakan di Indonesia sejak jaman kolonial. Di negara lain pun, konsep semacam itu baru dikenal sejak tahun 1970-an, misalnya di negara Inggris dikenal dengan sebutan archaeological heritage management, sedangkan di Amerika lebih dikenal dengan conservation archaeology atau cultural resources management (CRM) (Cleere 1989; Mayer-Oakes 1989). Pengertian CRM./konservasi atau pengelolaan sumberdaya arkeologis pun juga sedikit bervariasi antara satu definisi dengan lainnya. MayerOakes mengutip definisi "conservation" dalam The Airlie House report sebagai (Mayer-Oakes 1989) :

"An approach to archaeology based on a philosophy stressing the protection. preservation and/or managed use of the cultural resource base for future generations. Protection of representative sites and preservation of data through scientific study are major aspects of this approach".

Sedangkan Fowler (1982) mendefinisikan CRM dengan

"the application of management skills (planning, organizing, directing. controlling, and evaluating) to achieve goals set through the political process to preserve important aspects of our cultural heritage for the benefit of the American people".

Pernyataan Fowler bahwa CRM ditujukan bagi kepentingan masyarakat Amerika adalah disebabkan karena kutipan tersebut berbicara dalam konteks CRM di Amerika, tetapi definisi tersebut nampaknya dapat diterapkan di negara lain, juga di Indonesia. Fowler lebih jauh lagi menjelaskan bahwa istilah "cultural resources" mencakup segala sumberdaya yang berkaitan dan relevan dengan warisan budaya bangsa. Namun, dalam prakteknya CRM lebih memfokuskan perhatiannya terutama pada sumberdaya arkeologis historis dan prehistoris (Fowler 1982).

Dalam makalah ini digunakan istilah Pengelolaan Sumberdaya Arkeologis sebagai ganti istilah Cultural Resources Management walaupun keduanya secara definisi menunjukkan hal yang sama.

\section{B. Tujuan Pengelolaan Sumberdaya Arkeologis}

Adapun mengapa perlu dilakukannya praktek manajemen sumberdaya arkeologis terhadap tinggalan-tinggalan arkeologis adalah untuk melestarikan warisan budaya tersebut di satu pihak dan di pihak lain adalah untuk dapat memanfaatkannya bagi kepentingan masyarakat. Dalam susunan kalimat yang berbeda, tetapi mempunyai kesamaan maksud, Cleere (1989) mengatakan bahwa "archaeological heritage management has an ideological basis in establishing cultural identity, linlked with its 
educational function, it has an economic basis in tourism, and it has an academic function in safeguarding the database".

\section{Bagaimana dan Siapa yang Berhak Mengelola Sumberdaya Arkeologis.}

Perkembangan pengelolaan sumberdaya arkeologis di dunia sangat dipengaruhi oleh keadaan politik dan sosial masyarakatnya. Di samping itu, perkembangan pemikiran teoritis dalam keilmuan arkeologi juga telah melandasi pengembangan cara-cara pengelolaan sumberdaya arkeologis. Apabila kita membandingkan gerakan pemikiran arkeologi sebelum tahun 1980-an dan sesudahnya, akan terlihat jelas suatu pergeseran pemikiran dalam bidang pengelolaan sumberdaya arkeologis. Pengelolaan sumberdaya arkcologis yang berlangsung sebelum tahun 1980-an terutama dipengaruhi oleh gerakan pemikiran the New Archaeology yang selalu menempatkan para ahli arkeologi sebagai satu-satunya kelompok yang paling mengetahui dan berhak terhadlap pengelolaan dan pemanfaatan sumberdaya arkeologis. Sesudah tahun 1980-an muncul aliran pemikiran yang disebut dengan Arkeologi Pasca-prosesual (Post-processual Archaeology) yang lebih menekankan pada pendekatan historis, relatif, partikularistik, dan multivokal (Renfrew and Bahn 1991; Hodder 1995). Dengan pendekatan yang demikian tersebut, para penganut Arkeologi Pasca-prosesual memandang bahwa pengelolaan dan pemanfaatan sumberdaya arkeologis harus lebih terbuka terhadap pendapat liyan (the others), terutama dari masyarakat.

Di Indonesia, peranan pemerintah dalam pengelolaan sumberdaya arkeologis masih sangat kental, sehingga hampir seluruh kebijakan dan pendanaan pengelolaan dan pemanfaatan sumberdaya arkeologis dimonopoli oleh pemerintah. Mungkin sudah saatnya di Indonesia dikembangkan sebuah pendekatan baru yang berbeda dengan sebelumnya. Pendekatan yang sesuai dengan perkembangan sosial-politik dan aliran pemikiran arkeologi yang mutakhir adalah pendekatan partisipatoris. Pendekatan ini dalam aplikasinya akan melibatkan seluruh unsur dan potensi masyarakat dalam mengelola dan memanfaatkan sumberdaya arkeologis. Pelibatan masyarakat tersebut dimulai sejak awal perencanaan kegiatan pengelolaan, studi kelayakan, pelaksanaan, pemanfaatannya, dan bahkan sampai pengawasannya.

Berdasarkan situasi dan kondisi tersebut di atas, maka menurut penulis, pendekatan baru yang sesuai untuk diterapkan dalam pengelolaan sumberdaya arkeologis masa kini di Indonesia adalah pendekatan PRA (Participatory Rural Appraisal).

\section{PRA (Participatory Rural Appraisal)}

Tadjuddin Noer Effendi (1997) menjelaskan pergeseran dan perbedaan antara metodologi penelitian konvensional dengan partisipatoris. Dalam penjelasannya 
dikemukakan bahwa metode konvensional sangat tergantung pada peranan peneliti profesional tanpa mengikutkan peran serta masyarakat. Peneliti seolah-olah merupakan bagian yang terpisah dari masyarakat yang ditelitinya, sehingga semua penyusunan perencanaan dan proses penelitian dikerjakan seluruhnya oleh para peneliti. Masyarakat sebagai pihak yang diteliti tidak akan pernah tahu dan mengerti apa yang dikerjakan peneliti terhadap mereka sendiri. Selain itu, masyarakat memang tidak mempunyai hak kontrol atas jalannya penelitian atau dengan kata lain masyarakat kemudian tidak mempunyai tanggung jawab apa pun terhadap hasil penelitian (Tadjuddin Noer Effendi 1997).

Sebaliknya, metode partisipatoris lebih menekankan keikursertaan masyarakat dalam keseluruhan penelitian. Masyarakat akan dilibatkan dalam penelitian, sehingga mereka bersama-sama dengan para peneliti profesiaonal akan menyusun program penelitian dari awal penyusunan proposal sampai dengan penyimpulan hasil penelitian. Dalam hal ini tentu saja pencarian atau perumusan permasalahan akan juga dilakukan secara bersama-sama. Dengan demikian biasanya, permasalahan yang dihasilkan benar-benar mencerminkan permasalahan yang muncul di dalam kehidupan sehari-hari masyarakat yang akan diteliiti.

Berdasarkan atas tabel yang telah disusun oleh Fernandes dan Tandon (1993), Tadjuddin Noer Effendi (1997) menyusun kembali tabel yang menunjukkan perbedaan pokok metode penelitian konvensional dengan metode partisipatoris seperti di bawah ini:

Tabel 1. Perbedaan Metode Konvensional dengan Partisipatoris

\begin{tabular}{|l|l|l|l|}
\hline \multicolumn{2}{|c|}{ Langkah Kerja } & \multicolumn{1}{|c|}{ Metode Konvensional } & \multicolumn{1}{c|}{ Metode Partisipatoris } \\
\hline $\begin{array}{l}\text { Pilihan } \\
\text { Masalah }\end{array}$ & Apa & $\begin{array}{l}\text { Didasarkan pada kepentingan dan } \\
\text { disiplin peneliti profesional }\end{array}$ & $\begin{array}{l}\text { Didasarkan pada masalah yang } \\
\text { dihadapi }\end{array}$ \\
\cline { 2 - 4 } & Siapa & Peneliti profesional & Masyarakat dan peneliti profesional \\
\hline $\begin{array}{l}\text { Pilihan } \\
\text { Metode }\end{array}$ & Apa & $\begin{array}{l}\text { Survei desain eksperimental, } \\
\text { memanfaatkan kuesioner dan } \\
\text { instrumen canggih dan analisi } \\
\text { kuantitatif (statistik) }\end{array}$ & $\begin{array}{l}\text { Dessain didasarkan pada konsensus, } \\
\text { pemanfaatan instrumen empati dan } \\
\text { metode analisis kompleks }\end{array}$ \\
\cline { 2 - 5 } & Siapa & Peneliti profesional & $\begin{array}{l}\text { Konsensus bersama antara } \\
\text { masyarakat dan peneliti profesional }\end{array}$ \\
\hline Hasil & Apa & Publikasi dan presentasi seminar & $\begin{array}{l}\text { Perubahan situasi, peningkatan } \\
\text { pengetahuan dan kemampuan } \\
\text { masyarakat untuk melihat dan } \\
\text { merubah situasi mereka (muncul } \\
\text { kesadaran) }\end{array}$ \\
\cline { 2 - 4 } & Siapa & Peneliti profesional & $\begin{array}{l}\text { Dirasakan masyarakat dan peneliti } \\
\text { profesional }\end{array}$ \\
\hline
\end{tabular}


Dari tabel tersebut terlihat bahwa dalam penelitian partisipatoris masyarakat bukan hanya sebagai objek penelitian, tetapi dia juga sebagai pelaku peneliti masyarakat itu sendiri. Dengan demikian, masyarakat mampu melihat permasalahan yang mereka hadapi dan mampu juga memecahkan permasalahan tersebut. Berdasarkan paradigma penelitian seperti itu, maka aspek-aspek ideologis dan normatif yang dipegang erat oleh para peneliti konvensional akan sering hilang atau diabaikan (Fernandes dan Tandon 1993; Tadjuddin Noer Effendi 1997).

Lebih lanjut lagi Fernandes dan Tandon (1993) menggambarkan tahap-tahap penelitian dengan pendekatan partisipatoris ke dalam skema di bawah ini:

Skema 1. Tahap-tahap Penelitian dengan Pendekatan Partisipatoris.

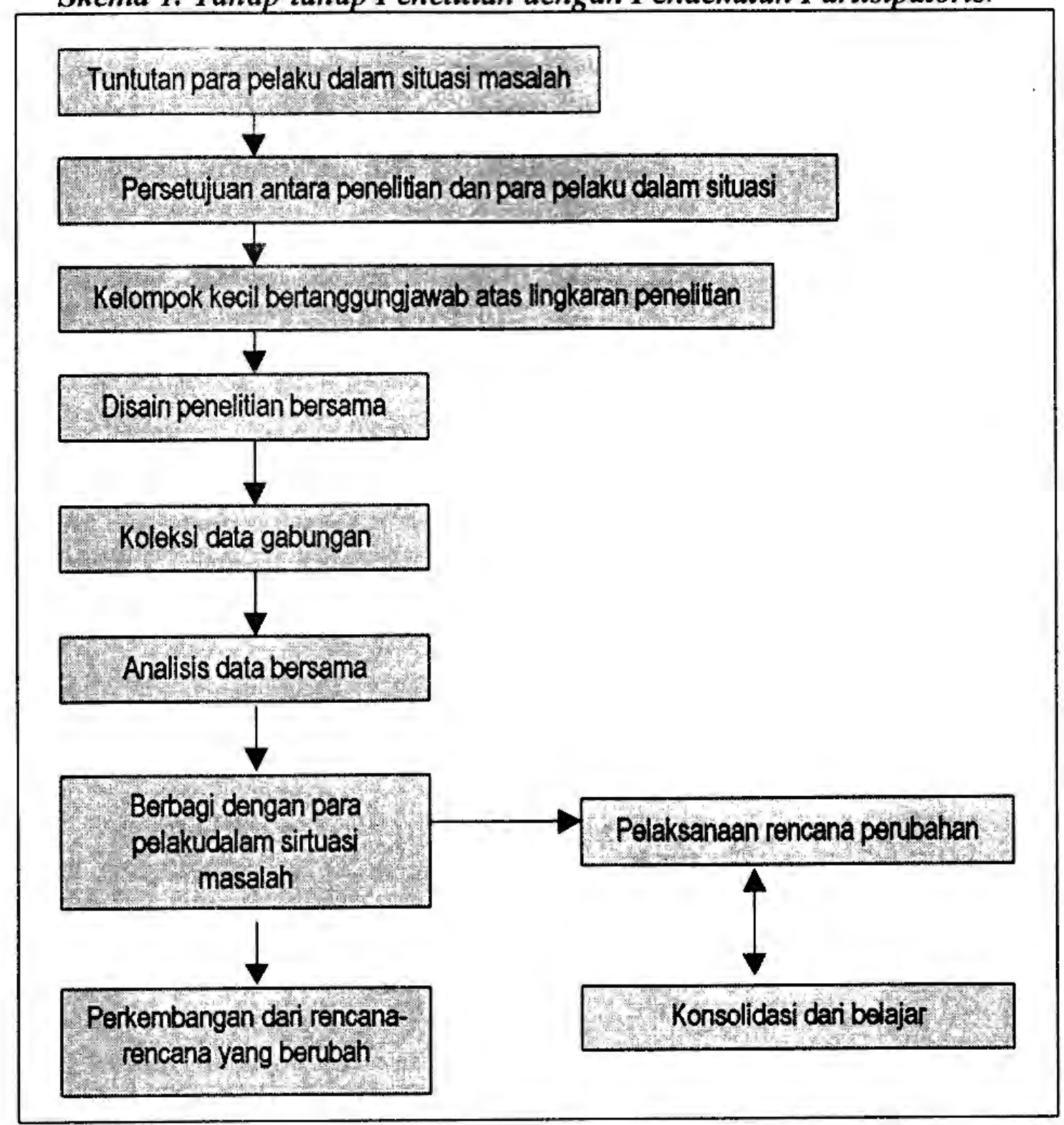


Robert Chambers (1996) menyatakan adanya tiga prinsip dasar dalam pendekatan PRA yang harus terjadi pada si peneliti dalam hubungannya dengan masyarakat yang ditelitinya, yaitu:

1. Sebagai fasilitator. Peneliti hanya bertindak sebagai pemberi fasilitas dalam bentuk memberikan fasilitas penyelidikan, analisis, dan hasil penelitian serta pemahamannya. Dengan demikian masyarakat akan dapat memliki dan mempelajari hasil penelitian.

2. Peneliti sebagai fasilitator harus berkesadaran dan bertanggungjawab yang tinggi dan kritis. Secara berkesinambungan fasilitator harus berani mengkoreksi dan menyempurnakan tingkah laku nya sehingga akan menjadi semakin baik.

3. Saling bertukar informasi dan ide, baik antara masyarakat dengan fasilitator maupun di antara fasilitator sendiri. Bahkan, sering juga dilaksanakan saling tukar-menukar kegiatan, pelatihan, dan pengalaman.

Dari ketiga prinsip di atas jelas terlihat bahwa pendekatan PRA pada dasarnya mengutamakan proses belajar dan mengajar, terutama bagi peneliti dan lebih-lebih bagi masyarakat.

Penelitian partisipatoris lebih menekankan pada proses penelitian itu, lebih dari sekedar mendapatkan hasil akhir penelitian. Berkaitan dengan penekanan pada "proses" dan tindakan pembelajaran di dalam penelitian partisipatoris, maka pada umumnya sebuah penelitian partisipatoris akan memperoleh beberapa pencapaian. Fernandes dan Tandon merumuskan tiga hal yang diharapkan akan dicapai dalam penelitian partisipatoris, yaitu (1993: kutipan langsung) :

(a) Perubahan dan tindakan sosial langsung merupakan salah satu dari hasil tersebut. Para pelaku dalam proses riset ikut serta di dalam usaha bersama untuk mengubah situasi mereka karena mereka menyadari seba-sebab situasi yang mereka alami sekarang ini, dan menyadari kemampuan mereka untuk menjadi pelaku perubahan.

(b) Pengetahuan yang bertambah mengenai situasi sosial tertentu merupakan hasil yang lainnya. Tidak seperti di dalam sistem klasik di mana peneliti dari luar memiliki monopoli pengetahuan, dalam pendekatan partisipatoris pengetahuan itu tersedia bagi peneliti dan pelaku dalam masyarakat tersebut. Hal ini memungkinkan para pelaku memulai proses pengambilan keputusan yang didasarkan atas pengetahuan itu.

(c) Kemampuan yang bertambah di antara para pelaku untuk memahami dan mengubah situasi mereka merupakan hasil lain yang juga penting. Ini merupakan akibat dari keyakinan diri yang baru yang mereka peroleh sebagai hasil dari upaya pencarian pengetahuan yang dikombinasikan dengan usaha pada tingkat aksi. Orang-orang yang selama itu dianggap tidak dapat menjadi sesuatu yang lain selain menjadi budak dan pelaksana perintah-perintah penguasa (pada tingkat riset: menjadi obyek-obyek kajian orang luar) kini dipandang mampu menganalisis dan memahami kenyataan mereka sendiri. Hal 
ini bermuara pada gambaran diri yang baru dan pada bertambahnya kemampuan untuk belajar dan bertindak. Inilah aspek edukatif dari pendekatan partisipatoris di mana para pelaku dalam situasi masyarakat tertentu mempelajari bagaimana belajar itu sendiri terjadi di dalam proses tersebut.

Berkaitan dengan bentuk tindakan sosial tertentu yang dihasilkan oleh penelitian partisipatoris, maka tentunya penelitian semacam itu akan mempunyai implikasiimplikasi politis yang jelas (Fernandes dan Tandon, 1993).

\section{Kemungkinan Penerapan PRA dalam Pengelolaan Sumberdaya Arkeologis}

Pearson dan Sullivan (1995) memberikan secara garis besar sebuah prosedur tahapan pengelolaan sumberdaya arkeologis sebagai berikut :

1. Identifikasi sumberdaya arkeologis. Dalam tahap ini dilakukan penentuan dan pendeskripsian lokasi, identifikasi, dan dokumentasi batas-latas situs yang mengandung sumberdaya arkeologis.

2. Penaksiran terhadap nilai penting atau kebermaknaan situs terhadap masyarakat atau sebagian masyarakat.

3. Perencanaan dan pembuatan kebijakan, dengan menimbang nilai penting situs (hasil kegiatan tahap sebelumnya) terhadap berbagai kepentingan lain. Pada tahap ini pengelola (manager) harus dapat menghasilkan kebijakan pengelolaan yang ditujukan bagi kelestarian (kebermaknaan) situs tersebut.

4. Implementasi dari kebijakan yang telah ditetapkan untuk mengelola situs tersebut di masa depan.

Kerangka kerja di atas adalah prosedur kerja yang dilaksanakan di hampir semua negara yang telah menjalankan pengelolaan sumberdaya arkeologis, perbedaan mendasar di antara negara-negara tersebut biasanya ada pada perangkat undangundang yang digunakan. $\mathrm{Di}$ Indonesia pun prosedur pengelolaan sumberdaya arkeologis dijalankan seperti itu.

Namun, seperti telah dikemukakan pada bagian terdahulu bahwa pengelolaan sumberdaya arkeologis di Indonesia sangat didominasi oleh negara. Berkaitan dengan dominasi negara tersebut, apabila dilihat secara mendalam, terutama dalam prakteknya di lapangan, terdapat satu hal yang dilupakan, yaitu keterlibatan kelompok masyarakat (lokal) dalam keseluruhan tahapan kerja pengelolaan sumberdaya arkeologis. Hari Untoro Drajat (1999) sebenarnya telah menyebutkan bahwa masyarakat merupakan salah satu pihak yang berperan dalam pengelolaan sumberdaya arkeologis di Indonesia, selain pihak pemerintah dan peneliti (akademisi). Akan tetapi, oleh Hari Untoro Drajat pihak masyarakat ditempatkan hanya sebagai pihak yang memanfaatkan sumberdaya arkeologis atau dengan kata lain tidak mempunyai peran dalam perencanaan dan pengaturan pengelolaan sumberdaya arkeologis. 
Di samping pihak negara, para ahli arkeologi di Indonesia juga meletakkan dirinya pada tempat yang "paling tahu dan paling berhak" menentukan pengelolaan sumberdaya arkeologis. Daud Aris Tanudirjo (1998) mengemukakan hal yang hampir sama sebagai berikut:

"Sumberdaya itu adalah milik masyarakat luas yang mempunyai beragam kepentingan. Jangan pula beranggapan bahwa arkeologi-lah yang seharusnya menentukan nasib sumberdaya budaya itu. Arkeologi harus meninggalkan arogansinya untuk seolah-olah menjadi satu-satunya pihak yang paling benar".

Akibat yang muncul dari adanya monopoli pemerintah (negara) dan keangkuhan ahli arkeologi dalam pengelolaan sumberdaya arkeologis tersebut adalah tidak kondusifnya sistem pengelolaan sumberdaya arkeologis bagi kepentingan masyarakat. Kepentingan masyarakat tidak pernah terakomodasikan dalam pengelolaan sumberdaya arkeologis yang ada selama ini. Sistem yang telah tercipta dan berjalan selama ini hanya diperuntukkan bagi aspirasi dan keuntungan pihak pemerintah dan ahli arkeologi.

Oleh karena hal-hal tersebut di atas, penulis dalam makalah ini menyodorkan sebuah pendekatan pengelolaan sumberdaya arkeologis yang lebih partisipatoris, atau dengan kata lain sebuah pendekatan pengelolaan yang lebih melibatkan peran masyarakat dalam keseluruhan proses pengelolaan. Pelibatan masyarakat ini didasari atas pertimbangan bahwa masyarakat lah sebenarnya pemilik sumberdaya arkeologis itu sendiri, sehingga mereka berhak juga untuk ikut memikirkan dan mengelola sumberdaya arkeologis mereka.

Pelibatan masyarakat dalam pengelolaan sumberdaya arkeologis secara yuridis diijinkan oleh UU No. 5 Tahun 1992 dan PP No. 10 tahun 1993, walaupun sebenarnya belum begitu jelas peraturannya. UU No. 5 Tahun 1992 pasal 18 ayat 2 menyebutkan diperbolehkannya masyarakat berperan serta dalam pengelolaan sumberdaya arkeologis (benda cagar budaya). PP No 10 Tahun 1993 pasal 42 berbunyi:

(1) Peranserta masyarakat dalam pelestarian atau pengelolaan benda cagar budaya dapat dilakukan oleh perorangan atau badan hukum, yayasan, perhimpunan, perkumpulan, atau badan lain yang sejenis.

(2) Peranserta masyarakat sebagaimana dimaksud dalam ayat (1) dapat berupa penyuluhan, seminar, pengumpulan dana, dan kegiatan lain dalam upaya perlindungan dan pemeliharaan benda cagar budaya.

Apabila kalimat "kegiatan lain dalam upaya perlindungan dan pemeliharaan benda cagar budaya" dapat diartikan bahwa masyarakat juga dapat berperanserta pula dalam perencanaan dan pelaksanaan pengelolaan sumberdaya arkeologis, maka tentunya PP No. 5 Tahun 1993 sangat kondusif bagi pelibatan masyarakat dalam pengelolaan sumberdaya arkeologis. Sebaliknya, apabila frase kutipan di atas mempunyai arti yang sempit yang hanya memperbolehkan peranserta masyarakat secara terbatas seperti kegiatan penyuluhan dan seminar, maka seyogyanya di masa mendatang peraturan tersebut sudah pada tempatnya direvisi. 
Skema di bawah ini menunjukkan sejauh mana pelibatan masyarakat lokal yang dapat dilakukan dalam pengelolaan sumberdaya arkeologis.

\section{Skema 2. Pengelolaan Sumberdaya Arkeologis yang Partisipatoris}
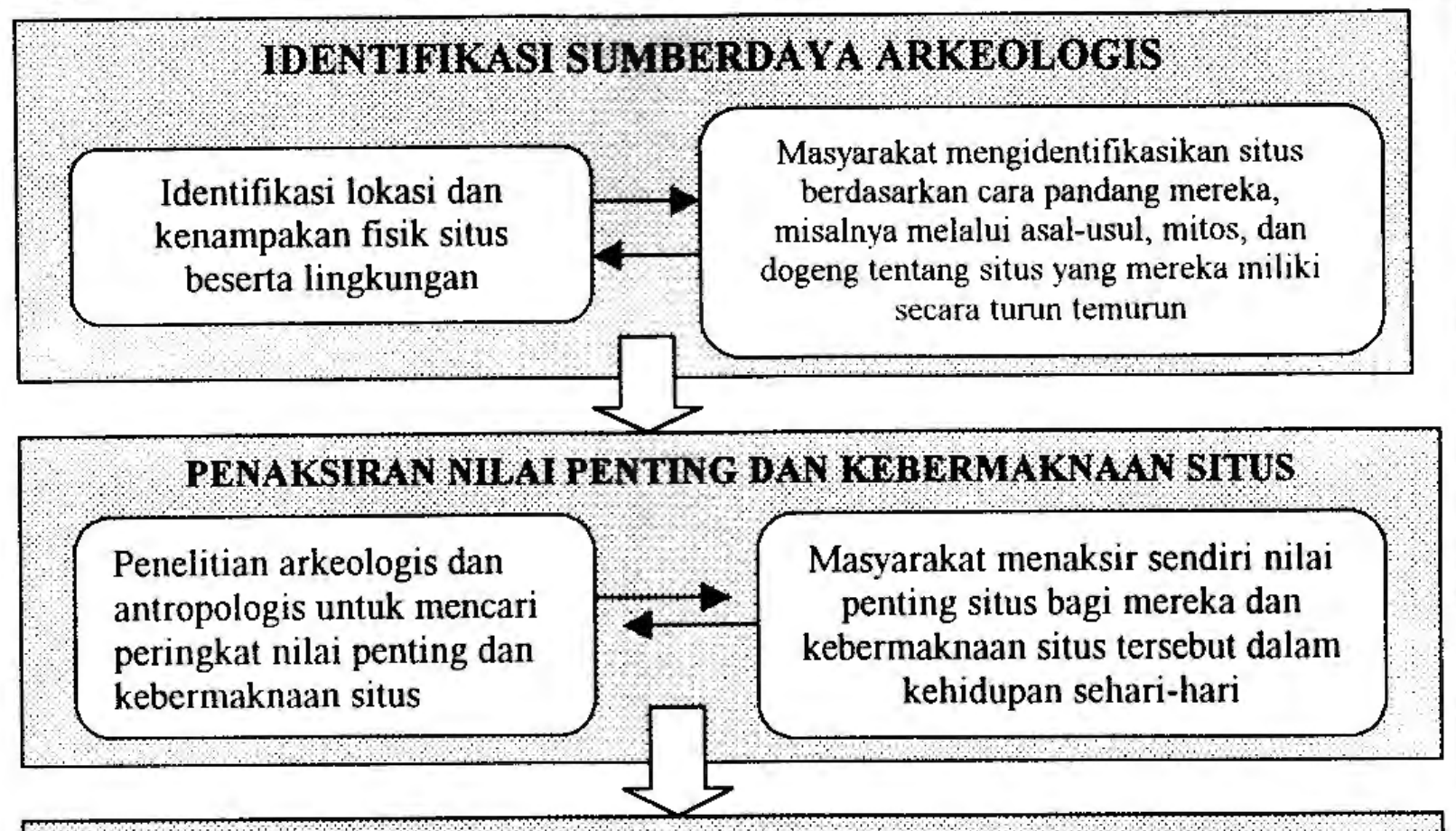

\section{PERENCANAAN DAN PEMBUATAN KEBIJAKAN}

Pemerintah, Akadernisi, dan Masyarakat lokal dudak bersama untuk membuat rencana pengelotaan sumberdaya atkeologis. Hasil diskusi tersebut dipergunakan bagi pemerintah untuk menyusun dan membuat kebjjakat.

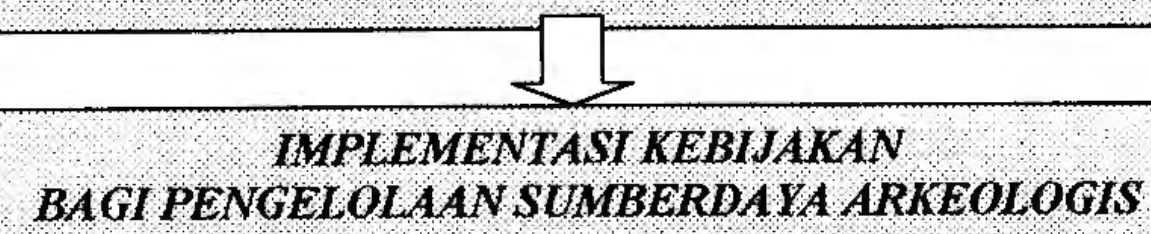

Pengelolaan sumberdaya arkeologis harus berpatokan pada community-based management. Masyarakat lokal dilibakan dalam jaringan sisten pengelolaan situs, baik dari segi pemanfaatar, perlindungan, pelestarian, naupun dari perdanaan

\section{MONTTORIVG DAN EVAL UAST}

Pemerintah, akademisi, dan nasyarakat secara bersama-sama nemantau dan mengawasi serta mengadakan evaluasi terhadap pelaksanaan pengelolaan sumberdaya arkeolog is. Masyarakat meniliks hak dan kewajiban untuk sclalu memonttor seluruh proses pengelolaan sumberdaya arkeologis. Hasti nonitor ini akan dípergunakan untuk mengevaluasi kegiatan pengelolaan tersebut. 


\section{Penerapan Pengelolaan Sumberdaya Arkeologis Partisipatoris di Kawasan Gunung Kidul}

Jurusan Arkeologi Fakultas Sastra Universitas Gadjah Mada saat ini memiliki program penelitian terpadu yang disebut dengan PTKA (Penelitian Terpadu Kawasan Arkeologis) Gunung Kidul yang diselenggarakan dalam tahapan lima tahunan. Tahap pertama PTKA Gunung Kidul sudah berlangsung selama dua tahun (1998 dan 1999). Tujuan diadakannya PTKA Gunung Kidul ini adalah (1) memberdayakan masyarakat Gunung Kidul melalaui pengembangan dan pemanfaatan potensi sumberdaya budaya yang mereka miliki secara kultural, sosial, dan ekonomis; (2) memperoleh gambaran menyeluruh tentang proses budaya yang terjadi di kawasan itu melalui penelitian multidisipliner, sehingga selain proses budaya itu sendiri, juga akan tersusun basis data budaya masyarakat Gunung Kidul (Tim PTKA Gunung Kidul 1999).

Hasil akhir yang ingin diperoleh Tim PTKA Gunung Kidul antara lain adalah tersusunnya Desain Museum Rakyat dan Desain Pengembangan Pariwisata. Menurut rencana kegiatan yang telah disusun, kedua program tersebut akan dilaksanakan melalui pendekatan yang berifat pelibatan masyarakat lokal atau partisipatoris. Desain Museum Rakyat sudah direncanakan akan dimulai dikerjakan pada tahun ketiga dari tahapan lima tahun pertama. Penyusunan desain ini akan diawali dengan beberapa dialog di antara berbagai unsur yang terdapat dalam masyarakat Gunung Kidul dan peneliti Tim PTKA Gunung Kidul hanyalah sebagai fasilitator semata. Masyarakat akan membicarakan potensi sumberdaya arkeologis mereka sendiri dan menemukan permasalahan-permasalahan yang mereka meiliki serta mencoba untuk memecahkannya sendiri. Setelah mereka mengetahui permasalahan dan solusi yang ada, mereka kemudian akan mulai mencoba membuat perencanaan/desain museum rakyat. Dengan proses penyusunan yang didasarkan atas potensi dan permasalahan yang benar-benar nyata di masyarakat seperti tersebut di atas, maka diharapkan desain yang tercipta akan benar-benar mewakili keinginan dan aspirasi masyarakat yang pada akhirnya akan memberdayakan masyarakat baik secara kultural, sosial maupuin ekonomis. Diharapkan desain tersebut sudah tersusun pada akhir tahap pertama PTKA Gunung Kidul (Tim PTKA Gunung Kidul 1999). Implementasi Desain Museum Rakyat tersebut direncanakan pada tahapan berikutnya, yaitu Tahap II.

Desain pengembangan Pariwisata juga akan disusun melalui proses yang hampir sama. Prinsip dasar yang dipakai dalam program penyusunan desain pengembangan pariwisata di Gunung Kidul tersebut adalah bahwa masyarakat lokal merupakan pemilik sumberdaya budayanya sendiri dan berhak mengelolanya, antara lain melalui pengembangan pariwisata daerah. Di samping itu, banyak penelitian empiris yang menjelaskan bahwa keterlibatan masyarakat lokal dalam "industri" pariwisata justru lebih menguntungkan bagi pengembangan pariwisata setempat (Hitchcock 1997). 
Dengan demikian, program penyusunan desain museum rakyat oleh Tim PTKA Gunung Kidul akan selalu melibatkan masyarakat secara partisipatoris mulai dari awal perencanakan sampai dengan pelaksanaan penyusunan desain. Seperti juga yang terjadi pada Desain Museum Rakyat, implementasi desain pengembangan pariwisata diharapkan akan terealisasikan pada penelitian Tahap II.

\section{Penutup.}

Makalah ini pada dasarnya berisi pemaparan alternatif pendekatan ban dalam pengelolaan sumberdaya arkeologis, yaitu pendekatan partisipatoris. Pendekatan ini di masa mendatang diyakini akan lebih sesuai diaplikasikan dan banyak diminati oleh para pengelola sumberdaya arkeologis. Hambatan dan tantangan tentunya akan selalu menghadang, tetapi penulis percaya bahwa rintangan yang ada jauh lebih kecil artinya dibandingkan dengan hasil akhir yang akan didapat, vaitu pelestarian sumberdaya arkeologis sekaligus pemberdayaan masyarakat baik secara kultural, sosial dan ekonomis.

\section{KEPUSTAKAAN}

Chambers, Robert. 1996. PRA Participatory Rural Appraisal, Memahami Desa Secara Partisipasi. Penerbit Kanisius, Yogyakarta.

Cleere, H.F. 1989. Archaeological Heritage Management in the Modern World. Unwin Hyman, London.

Effendi, Tadjuddin Noer. 1997. "Metodologi Ilmu Pengetahuan: Kajian Pergeseran dari Positivisme menuju Partisipatoris". Disampaikan dalam: Seminar Metodologi Penelitian Bidang Humaniora. Yogyakarta, 9 Juni 1997, Universitas Kristen Duta Wacana.

Fernandes, Walter dan Rajesh Tandon. 1993. Riset Partisipatoris Riset Pembebasan. Gramedia Pustaka Utama dan Yayasan Karti Sarana, Jakarta.

Fowler, Don D. 1982. "Cultural Resources Management". Dalam: Michael B. Schiffer, (ed.). 1982. Advances in Archaeological Method and Theory. Vol. 5. Academic Press, New York.

Hari Untoro Dradjat. 1999. "Manajemen Sumberdaya Budaya", Buletin Cagar Budaya. Vol. 1, No. 1, Maret 1999, him. 3-7. 
Hitchcock, Michael. 1997. "Heritage for Whom? Tourism and Local Communities". Dalam: Wiendu Nuryanti (ed.). Tourism and Heritage Management. Gadjah Mada University Press, Yogyakarta.

Hodder, Ian. 1995. Interpreting Archaeology. Routledge, London and New York.

Kompas. "Arca di Tengah Sawah itu...". Harian Kompas, 31 Mei 2000. hlm. 1 \& 11.

Mayer-Oakes, William J. 1989. "Science, Service and Stewardship - a Basis for the Ideal Archaeology of the Future". Dalam: H.F. Cleere, (ed.). 1989. Archaeological Heritage Management in the Modern World. Unwin Hyman, London.

Pearson, Michael and Sharon Sullivan. 1995. Looking After Heritage Places. Melbourne University Press, Melbourne.

Renfrew, Colin and Paul Bahn. 1991. Archaeology, Theories, Methods, and Practice. Thames and Hudson Ltd., London.

Sedyawati, Edi. 1997. "Potential and Challenges of Tourism: Managing the National Cultural Heritage of Indonesia". Dalam: Wiendu Nuryanti (ed.). Tourism and Heritage Management. Gadjah Mada University Press, Yogyakarta.

Tanudirjo, Daud Aris. 1998. "CRM sebagai Manajemen Konflik" Artefak. No. 19/Februari 1998. Hlm. 14-18.

Tim PTKA Gunung Kidul. 1999. Profil Penelitian Terpadu Kawasan Arkeologis (PTKA) Gunung Kidul. Jurusan Arkeologi Fakultas Sastra UGM, Yogyakarta. 